\title{
ANDRA GRĪNBERGA DRUKĀTAIS VĀRDS
}

\author{
Voldemārs Hermanis, žurnālists-apskatnieks
}

Avīzes latviešu valodā iznāk teju divsimt gadu, gan ne vairs kā galvenie nacionālo un pasaules ziṇu vēstneši. Šo misiju pārṇēmuši tīmekḷa plašsaziṇas mediji, sociālās tīklošanās vietnes, modernās tehnologijas. Tāpat sabiedrība tagad maz informēta par žurnālistiem, kuri strādā preses izdevumu redakcijās un diendienā neparādās tālrādes ekrānos. Pavisam nedaudzi savu profesionālo pieredzi tā vai citādi apkopojuši un nodevuši lasītājiem.

Uz šāda fona Latvijas Avīzes ilggadējais korespondents Andris Grīnbergs ir labi pamanāms izṇēmums. 2019. gadā iznāca viņa grāmata Kustinu dzīvi jeb atskats uz paša 60 gadiem "žurnālista ceḷos un neceḷos" (Kustinu dzīvi: 60 gadi žurnālista cel̦os un neceḷos). Sācis rajonu avīzēs Kandavā, Kuldīgā, Limbažos, turpinājis Latvijas kompartijas centrālorgānā Cīna, neilgu laiku arī Neatkarīgajā Cīn, $\bar{a}$, bet kopš 1993. gada uzticīgi kalpojis Lauku Avīzei. Gadu skrejā mainījušies laikraksta redaktori, valdības un ministri, mainījies avīzes nosaukums. A. Grīnbergs palicis savā Jēkabpilī un Latvijas Avīzes līdzveidotāju pulkā.

2020. gada lielās pandēmijas aizsegā atkal SIA Latgales druka tipogrāfijā iespiesta A. Grīnberga jaunākā grāmata Katru dienu ar piesitienu. To nevar uztvert savādāk kā Kustinu dzīvi turpinājumu. Gandrīz vai identisks arī vizuālais pieteikums uz titulvāka: pirmajā reizē autors pie motocikla stūres, otrajā - pie airiem Daugavā. Izdevējs tāpat kā pirmajā reizē - Latvijas Mediji Rīgā.

A. Grīnbergu kā savu bijušo kolēǵi es definētu kā daudzdabi ar plašu interešu loku. Cauri gadiem bijis dzejnieks, reportieris, šahists, cilvēkpētnieks un mērens atturībnieks. Šajās rindās - par dažiem pavērsieniem un situācijām viņa korespondenta gaitās, par žurnālista suverenitātes zonu, par redaktora lomu raksta ievirzē. Un mazliet arī par spilgtiem notikumiem un ievērojamām personībām, kurām veltīts A. Grīnberga drukātais vārds.
Jau pirmajā grāmatā viṇa uzmanības lokā bija vairāki Sēlijas kultūras un sabiedriskie darbinieki - Velta Toma, Pēteris Martinsons, Lūcija Ķuzāne, Jāņa Vesẹ̦a mazmeita Daiga, visā Latvijā pazīstama no dokumentālās filmas Škēersiela. Tēlaini ieskicēts viens no šī novada redzamākajiem kultūrvēstures šūpuḷiem - Jāṇa Jaunsudrabiņa muzejs Riekstiņos. Iepazīstamies ar žurnālisti un rakstnieci Skaidrīti Gailīti, savulaik represēto publicistu Ilmāru Knaǵi. Visi viṇi, tāpat kā citi abu grāmatu varoṇi, dziḷām saknēm ieauguši vietā, ko autors dēvē par Jēkabmiestu, kas plašākā ietvarā uzlūkojama kā Sēlija.

Kustinu dzīvi var lasīt kā miniatūru, portretskiču, rotalịgu tekstu un dzejas rindu savijumu. Vai arī kā uzmetumu mazai kinonovelītei, piem., Pēc peldes - rokudzelžos, kur jēkabpiliete Inta Zagorska ar sievišķu viltību panāk pilsētā meklēta noziedznieka aizturēšanu. A. Grīnbergs stāsta par savu žurnālista gaitu sākumu Kurzemes pusē, līdz nonāk pie atmodas, kad pats ticis izvirzìts par Tautas frontes Jēkabpils rajona nodaļas priekšsēdētāju. Mūsu LTF dzimšanas aizmetņiem veltīta apakšnodaḷa Kas palika aiz Gorbunova smu$k \bar{a} s$ frizūras?' ${ }^{1}$.

Kopumā runa ir par mobilu žurnālistu un sabiedriski aktīvu cilvēku, kurš ņēmis vērā kāda agrākā kolēǵa padomu: "Ja esi labs rakstītājs, nelien priekšniekos." Pavisam konkrēta situācija restaurēta grāmatā Katru dienu ar piesitienu $^{2}$, kad bijušo tautfrontieti A. Grīnbergu no iecelšanas augstā amatā paglābis valdības vadītājs Vilnis Bresis.

Varas institūciju - kā vietējo, tā valsts līmeņa - centieni pieregulēt un iegrožot žurnālistus ir mūžseni kā pasaule. Tā nav gluži caurviju tēma A. Grīnberga grāmatās, bet daudzviet piesaukta un autora darba rutīnā

\footnotetext{
Grīnbergs 2020, 84-87.

2 Turpat, 107-109.
} 
balstīta. Atstāsim aiz iekavām jezgu, kas sekoja viña asajai kritikai, kura bija adresēta toreizējam Jēkabpils rajona LKP pirmajam sekretāram Arkādijam Vrubḷevskim (1986). Tie bija Cīnas korespondenta gadi, vēl vienpartijas varas monopola laiks.

Pietiek principiālu sadursmju arī daudzpartiju demokrātijas Latvijā. Polemikā ar varas pārstāvjiem A. Grīnbergs allaž aizstāvējis jēkabpiliešus, vinuu skatpunktu. Vajadzīgā brīdi kopā ar tiem atsedzis "Rīgas kungu" tukšvārdību, intervējis, uzmundrinājis. Lauku sievām muti neaizbāzis $s^{3}$, viņas nekḷūdīgi redz, kā Saeimas deputāts un Tautas partijas vadītājs Andris Šksēle Jēkabpilī izvairījies atbildēt uz būtiskiem jautājumiem.

Interesantas ir A. Grīnberga atzinas un Galvas treniņš ${ }^{4}$ par tēmu "Kas ir žurnālists?". Sava veida kvintesence ietverta tēzē par "balansēšanu starp iespējamo un neiespējamo". Vai arī pašuzmundrinājums "tēlaini domāt, radoši izpausties". Daudz pašatklāsmes ir pirmajā grāmatā lasāmajā Intervijā pašam ar sevi ${ }^{5}$.

Sava veida pienesums latviešu preses vēsturē ir apakšnodaḷas, kas veltītas trim redaktoriem. Rakstot par Cīnas ilggadējo šefu Jāni Britānu, A. Grīnbergs neslēpj sava priekšnieka laipošanu atbilstīgi LKP CK vadlīnijām. Vienlaikus raksturo vinu kā kultūras cilvēku, kas sapratis un aizstāvējis rakstniekus, māksliniekus, savus žurnālistus.

Apakšnodaḷa Krustiņa laiks ${ }^{6}$ ir stāsts par mācībām, kādas autors guvis no Lauku Avīzes ilggadējā redaktora un procesa virsvadītāja. Voldemāru Krustiņu kā nopietnu konkurentu vērtējuši pārējie dienas laikrakstu redaktori. Sākot ar to, kāds viņam "nags" spēcīgas komandas veidošanā. Pāri visam stāvējis augsts prasīgums, tēmu atlase ("LA jāraksta par to, par ko neraksta vietējā prese"), savas avīzes prestižs. Kā redaktors bijis neaprēķināms, bet, citējot A. Grīnbergu: "Nebūtu Krustiņa, nebūtu Lauku/Latvijas Avīzes." Nebūtu šīs augstās latinas, varbūt netaptu avīzes raksts Traǵēdija

Grīnbergs 2020, 88-90.

4 Turpat, 114-117.

Grīnbergs 2019, 213-220.

6 Grīnbergs 2020, 194-197.
Jêkabpilī: policisti šauj uz policistiem ${ }^{7}$ un $\overline{1}^{-}$ dzīgas publikācijas.

Mazliet cits stāsts par Andri Jakubānu, kurš redaktora krēslā nonācis 1990. gada augustā, un viņa tuvāko līdzgaitnieku Ëriku Hānbergu. Jakubāna iesaukums ${ }^{8}$ bijis starta laukums vairākiem žurnālistiem, kuru vārdi Latvijā labi zināmi. Par to savās atmiņās dalās Nellija Ločmele, Aiga Pelāne un citi: ne katra redakcija gatava riskēt, pieplusējot štata darbiniekiem jauninus praktikantus no universitātes, kā A. Jakubāns. Neatkarīgās Cīṇas redaktora biedrs E. Hānbergs A. Grīnberga grāmatā Katru dienu ar piesitienu tuvplānos parādās vairākkārt, lielākoties gan draiskās nenopietnībās. Savukārt Dzintra Ciekurzne-Mozule, Vita Bērziņa-Krauja, Dace Dišlere-Kokareviča (1957-2019) savas pirmās ugunskristības izgājušas vecajā $C \bar{\imath} n \bar{a}$. Meistari nekrīt no gaisa, bet dažkārt - arī no ideoloǵiska sprosta.

A. Grīnbergs abās grāmatās neaprobežojas ar savu dzīves gaitu rotaḷīgu apceri. Līdztekus viņš mēǵinājis savilkt kopā redakciju un žurnālista pieredzi, pastāvot un darbojoties varas un elitāro grupu atvēlētajā laukumā. Viṇš neskopojas ar paldies redaktoriem, "kuri palaiž vaḷā - peldi!". Simpātiski ir daudzie dzīvesstāsti, itin bieži ieskicēti un uz kāda paradoksa balstīti. Nevar neizcelt dižajam sēlim akadēmiķim Jānim Stradiṇam veltītās lappuses Piesitienu izskan̄ā: bez viṇa šis kultūrvēsturiskais novads tik augstu nepaceltu Sēlijas karogu, savas identitātes meklējumus latviskajā Latvijā. Autors Jēkabpilij pietuvinājis arī Marinu Kosten,ecku, Andu Līci, vēl atmodas laikā Itu Kozakeviču un citas ievērojamas personības.

Atsevišḳos gadījumos A. Grīnberga rotaḹigais vēstījuma stils raisa pretjautājumus. Pieṇemsim, ka administratīvi teritoriālajai reformai kā pēdējo gadu karstajam kartupelim Latvijas novados pietiek ar gabalinu Iebrauc auzās... Kā tikt $\bar{a} r \bar{a} ?^{9}$. Autors nepretendē uz analītiskiem pārskatiem, viņam tādas tiesības. Bet dažkārt problēmu mezgls, maigi sakot, tikai "apgrābstīts". Piemēra pēc jautājums: kas noticis ar Preses namu Rīgā. A. Grīnbergs neslēpj, ka tas bijis uz mēles viņa laikabiedriem

\footnotetext{
7 Grīnbergs 2020, 130.

Turpat, 204-206.

9 Turpat, 144-145.
} 
Kuldīgas preses 110 gadu jubilejas reizē. Man arī. Kas tā samisējās pēc 2008. gada, kad klajā nāca viņa paša pieminētā "pārbagāta un garā pārpriecīga grāmata Preses nams. Ne mirkli nav rimis"? Pa jokam izmestā atbilde, ka tur Divi logi joprojām gaiš $i^{10}$, nav vairāk vērta kā politiķu tukšvārdība. Par celulozes rūpnīcas būvi jeb Ozolaines sāgu diskusijas bijušas karstu karstās. Var to visu uztvert kā nobungotu stāstu, bet varēja arī savam novadam un tā ḷaudīm veltītā grāmatā kādu dzirdamāku piesitienu pielaikot.

Kā pievienotā vērtība korespondenta un dzejnieka A. Grīnberga tekstos ir valoda un izklāsta raitais ritējums. Janīna Kursīte otrās grāmatas ievadā to formulē kā "skaistos grīnbergismus". Profesorei ar smalko valodniecisko dzirdi nepaslīd garām žurnālista dz̄ives gaitās akumulētās izteiksmes nianses, smeķa izgaršojums un apvidus vārdi. Vienai pašai niedrzālei, kā izrādās, ir vairāki nosaukumi - spulgzāle un A. Grīnberga lietotais “miežabrālis”.
Kāds vārds noteikti būtu sakāms par šahu kopā ar lielmeistariem Mihailu Tālu un Zigurdu Lanku, par dzeju savijumā ar Knutu Skujenieku un Andri Akmentiņu, par vairākiem citiem rīdziniekiem, jēkabmiestiešiem un ventspilniekiem. Visus abās grāmatās intervētos vai ieskicētos varoņus nepiesaukt. Vēl tikai piezīmējams, ka poligrāfiski kvalitatīvais drukas darbs dienas gaismu ieraudzījis, pateicoties vairāku ziedotāju - kā privātpersonu, tā novadu domju - finansiālam atbalstam. Samērā bagāti ilustrētas abas grāmatas, Piesitienos sarindotas arī dažādu gadu krāsainas fotogrāfijas.

Savā dzīves jubilejas gadā (2020) A. Grīnbergs sparīgi skandējis:

Maijā cerinini zied zili,

Brauc man līdz uz Jēkabpili!

Par laimi, pilsēta abos Daugavas krastos ir tikai skatu tornis, no kura šis divrindes autors pārlūko krietni plašāku panorāmu un uzrunā patiesi daudzskaitlīgu laikabiedru loku.

10 Grīnbergs 2020, 143-144. 